\title{
Creative Coercion in Post-Katrina New Orleans: a Neighborhood Strategy to Address Conflict in Networks
}

\author{
Stephen Danley \\ Rutgers-Camden University
}

\begin{abstract}
The study of relationships within networks has traditionally focused on concepts such as cooperation, collaboration and other forms of partnership (Brown \& Keast 2003). The assumption has been that actors in a network have shared vision and are working together. This study tests that idea by using mixed methods and ethnography to examine 15 neighborhood associations in post-Katrina New Orleans, and 71 of their relationships within policy networks. Contrary to our typical understanding of networks, neighborhood associations engage not just in partnership, but also in power struggles. When excluded from policy networks, neighborhood associations use creative coercion to ensure their voice is heard. Facing a power deficit, these associations look for informal levers to assert themselves into policy negotiation. The result is creative and coercive measures, such as co-opting elections, bribery, blackmail and what one neighborhood activist calls 'guerrilla warfare.' These conflicts force a reconsideration of networks. Networks are not solely homes of collaborative action; they are also the location of sharp power struggles over priorities.
\end{abstract}

\section{Introduction}

Provan and Kenis (2008) argue that in studying networks, academics focus on the volume of relationships and the outputs created by those links. They call for increased attention to the nature of relationships within networks. This paper focuses on these relationships, using postKatrina New Orleans as context for a series of case studies on neighborhood associations and their networks. ${ }^{1}$ In doing so, it radically transforms and redefines the typical conception of such relationships, moving beyond configurations such as Brown and Keast’s (2003) categorization of relationships as being collaborative, cooperative or coordinative. Brown and Keast's classifications, and the broader literature on which they are built, fundamentally envision networks as working together. An in-depth look at policy networks in New Orleans

\footnotetext{
${ }^{1}$ This research is part of a broader inquiry into these issues. Cosmopolitan Civil Societies Journal, Vol.7, No.1, 2015 
shows that this is not the case. Conflict is a key feature of networks, and conflict is a reaction to being excluded from them. New Orleans neighborhood associations are creatively coercive about joining networks. When they have little power or are actively excluded from such networks, they seek levers from outside the policy system. These creative tools are their 'weapons of the weak' (Scott 1985) and allow them a voice in matters critical to their locale.

This reframes networks. No longer do networks serve only as partnerships to make policies more efficient. Instead, urban policy networks are the scene of community conflict made famous by Alinsky (1971). Creativity is critical to these conflicts; excluded neighborhoods enact strategies to increase involvement and voice.

\section{Literature}

Dahl (1961) famously asked 'Who Governs?' The use of the term governance has changed over time (Kooiman 1993) to include more actors in networks. The new governance literature highlights the roles of additional actors in policy networks. Network governance highlights the relationship between these new actors, particularly when they interact in informal, nonhierarchical ways (Sørenson \& Torfing 2005). Brown and Keast (2003) categorize the different types of relationships community groups within networks can have. These three core concepts (new governance, network governance, and relationship categories) set the stage for a more specific discussion of power and conflict with policy networks.

Scholars claim that increasingly, 'public policy is less of a governmental dictum and more of an ongoing negotiation among government and non-government actors (Katz \& Mair, 1995; Castells, 1996; Blumler and Kavanagh, 1999; Ornstein and Mann, 2000; Bingham et al, 2005a; Blyth and Katz, 2005)' (Crozier, 2008 p. 3). While Crozier makes an empirical claim, other scholars soften the claim arguing, 'the idea of a sovereign state that governs society topdown through laws, rules and detailed regulations has lost its grip and is being replaced by new ideas about a decentred governance based on interdependence, negotiation and trust' (Sørensen \& Torfing, 2005, pp. 195-196). Kooiman (1993) argues that the term 'governance' entered the literature in the 1990s. Stoker (1998, p. 17) notes this shift and argues that it no longer only refers to what government does, but to a broader process. Stoker (1998) is not alone in noticing this shift in the understanding of governance. Forrest (2003, p. 593) argues that governance has moved from 'centrally steered’ to being 'negotiated, multi-actor, 
interorganizational relations that link together state and society’. Bogason and Musso (2006, p. 4) describe this new term as referring to 'an analytic focus, emphasizing process rather than formal organization, with a gradual evolution to recognition of processes as networks'.

Scholars working within the new governance paradigm look to sharpen the analytical understanding of what occurs when more actors are involved in policy networks. Network governance is directly derived from new governance, but includes a more formal definition and contains a number of theoretical insights and tools that make it applicable to the urban context. In particular, network governance stipulates that relationships between actors in networks be non-hierarchical and that the policy process be a negotiation.

Jones et al. (1997) define network governance as patterns of interactions in exchange and relations and flows of resources between independent units. These two basic concepts, independence and relationships, are common in definitions of network governance.

Network governance research spans multiple generations, from theoretical discussion, to examples of case studies, to understanding the democratic implications of non-hierarchical, negotiated networks (Torfing 2005). This work pushes that boundary, by extending beyond single case studies to look at a cornucopia of different examples of relationships between neighborhood associations and other organizations (from non-profits to elected officials) in post-Katrina New Orleans.

Much of the discussion around community participation in network arrangements is contextualized by a need to decrease the costs of public services (see Rhodes 1996). This is a core theme in network governance literature, where Rhodes explicitly describes governance as being about New Public Management and Stoker (1998, p. 39) calls governance, 'the acceptable face of spending cuts'. More recent research focuses on the benefits of using networks to provide social services (see Goldsmith and Eggers, 2004). Brown and Keast (2003) take this discussion in another direction, shifting the focus away from efficiency and towards types of relationships.

One understanding of networks argues that they increase the efficiency of social services through market mechanisms such as competition; this is an extension of the logic of new public management (Rhodes, 1996). But other scholars and politicians trumpet networks because of their collaborative power. In particular, Katz and Bradley’s Metro Revolution 
(2013) focuses on how cities are not only distinct units but part of global networks. Locally, Katz and Bradley argue for cooperation between networks of suburban and urban municipalities. William Eggers and Stephen Goldsmith, the former mayor of Indianapolis and deputy mayor of New York City, make the same argument on an even more local scale in Governing by Networks (Goldsmith and Eggers, 2004), arguing that the future of governance is in the management of local networks such as those that a city uses to provide its social services. Provan and Kenis (2008, p. 229) get to the heart of this line of thinking, claiming:

'The advantages of network coordination in both public and private sectors are considerable, including enhanced learning, more efficient use of resources, increased capacity to plan for and address complex problems, greater competitiveness, and better services for clients and customers'.

Brown and Keast (2003) are a part of this second class of network theorists, who argue that working together provides new opportunities to improve efficiency. They classify relationships within these networks as the '3Cs'. ${ }^{2}$ These categories are cooperation, coordination and collaboration. The categories are based upon differing levels of partnership. Cooperation is the least formal of these configurations, featuring short, informal relationships (Hogue 1994; Cigler 2001; Lawson 2002) in which organizations share things such as information and space, but still have autonomy (Winer \& Ray 1994; Cigler 2001; Mulford \& Rogers 1982; Melavillee \& Blank 1991). Coordination is also short-term, but involves additional planning and coordination (Mulford \& Rogers 1982; Daka-Mulwana 1995; Lawson 2002, Litterer 1973, Lawson 2002). Finally, Brown and Keast (2003, p. 8) describe collaboration as 'the most stable and long term' relationship, with 'comprehensive planning and well-defined communication channels.'

The classification of the '3Cs' in terms of working together harbors an implicit assumption that network governance is a viable strategy because partnership leads to more efficient outcomes. But in doing so, Brown and Keast ignore the possibility of power struggle and conflict within policy networks. In the urban context, there is a long history of conflict as part

\footnotetext{
${ }^{2}$ Brown and Keast narrow the five categories of relationships from "informal, cooperative, coordination, collaborative and integrative” (Hogue 1994; Cigler 2001; Leutz 1999; and Szirom et al. 2002), and build upon the five companion 'c words' for integration used by Lawson (2002): co-location, communication, coordination, collaboration and convergence. Brown and Keast (2003) use the more recent consensus that has emerged (see Winer \& Ray 1994; Konrad 1996 and Fine 2001) around the use of 3Cs: cooperation, coordination and collaboration.
} 
of the toolkit for progress. That can be through social movements (Anyon 2005), neighborhood conflict (Arnold 1979), and community organizing (Alinsky 1971).

Each of these examples refers to communities using policy networks as a way to gain power. In doing so, they reflect a movement in the philosophical understanding of power, from power of one person over another (Lukes 1974; Hunter 1969) to power of people (and organizations) over each other (Foucault 1978; Gaventa 2003). In the latter philosophical approaches, people and organizations can be interdependent; power does not have to be complete and dominant. Those in positions of weakness can still exert power over those in positions of strength (and those in positions of strength can, of course, exert power back over the weak).

By discussing power in the context of urban policy networks, this study examines an aspect of the structure or agency debate (see Hayward \& Lukes 2008), in which sources of power are seen to be systematic or individualistic. In one corner of that debate, authors have specifically looked at how 'weapons of the weak' (Scott 1985) over time, fuel resistance to power structures, or the 'power of the powerless' (Havel et al. 1985) in which rejecting symbols has a similar effect. But that discussion has not reached the discussion of networks, where networks are seen not as sites of power struggles but as opportunities for partnership and efficiency gains.

This research provides a link between this philosophical arm of the study of power, the urban tradition of social movement, and community organizing. This research shows that neighborhoods in New Orleans not only find themselves in conflict over the construction and direction of networks, but also use specific strategies to address their power deficit.

\section{Methodology}

This research is part of a larger inquiry into the priorities and strategies of neighborhood associations in post-Katrina New Orleans. That study focuses on New Orleans as a result of the paucity of comparative examples in network governance as most studies focus on a single example of network governance. The post-Katrina New Orleans context provides an excellent example to compare and contrast multiple cases of network governance in which neighborhood associations join policy networks to pursue their objectives. 
On August $29^{\text {th }}, 2005$, Hurricane Katrina hit New Orleans. The resulting flood caused $\$ 60$ billion in damages (Birkland, 2006) and over 1,000 deaths. Just days before, the city called for a full evacuation. At the time, it was the largest evacuation in the country's history. Eighty percent of the city flooded after the storm, as New Orleans, a city shaped like a bowl, filled up with water, endangering the lives of those who stayed. New Orleans lost not just lives, but key infrastructure, leaving the city with a series of policy decisions and controversy over who should make those decisions. For residents struggling to find a way to return to the city, neighborhood associations were a key way to stay connected and attempt to have a voice in the city's recovery.

Neighborhood associations have long been part of the discussion of the urban eco-system (De Tocqueville 1835; Arnold 1979), but they have taken on a particularly important role in the post-Katrina context (Ahlers \& Hummel 2007; Chamblee-Wright 2008). After Hurricane Katrina, these organizations took on a variety of roles, some becoming watchdogs, some providing services to their residents, some engaging in fierce conflict with their elected officials or developers. In doing so, neighborhood associations became an ideal mechanism with which to study network governance. They clearly meet the theoretical criteria: they have no formal relationship with government or others in their networks, and they are an actor from outside the traditional sphere of government. New Orleans was forced to reexamine many of its public systems after the devastation of Hurricane Katrina; these neighborhood associations engaged in a wide range of activities in a wide range of networks, creating an almost unparalleled chance to study multiple cases of network governance.

Doing so is not easy. Neighborhood associations are notoriously difficult to contact; information from city government indicated that neighborhood associations sometimes disappeared from the mayoral administration's eye only to reappear a decade later. As a result, this study uses a mixed methods approach to attempt to triangulate these associations, their activities and their motives. These methods include: ethnography, survey, document analysis and interviews.

The case for mixed methods research is rooted in both the difficulty of penetrating neighborhood-level processes and the tendency for non-profits to tailor their answers to their audience (Stablein 1996). Using multiple methods expanded access to these associations. The 
methods built upon each other. Ethnography provided important context and allowed for a strategy of repeatedly showing up to build trust, which was built over three years of study, and approximately six months a year in the field. Ethnography also allowed for verification of claims in interviews. The survey, essentially a census conducted in collaboration with a now-defunct non-profit called City Works, established a baseline of organizations from which to draw a sample. That sample was stratified by income, ensuring that this study did not simply draw case studies from the strongest, most visible neighborhood associations as was often done after the storm (see Chamblee-Wright 2008; Ahlers \& Hummel 2007).

Participation rates for both the survey and the sample of neighborhood associations for document analysis and interviews were extremely high, in part due to process of the researcher becoming a familiar face in the region over a number of years. Participation in the survey was $65 \%$, which would have been higher except many organizations from the sampling frame simply did not exist. Eighty-eight percent of associations selected for the second stage of the study chose to take part, by providing documents and engaging in interviews, with $93 \%$ of potential interviewees participating.

This second stage was characterized by a document analysis of each neighborhood association's historical documents. These mostly consisted of meeting minutes, but association leaders helped strategize to provide comprehensive documentation where possible, including emails, flyers, blogs and other historical placeholders. The document analysis was conducted based upon Mayhew’s (2002) ‘action’ analysis. It also provided the foundation for interviews, allowing the study to go past associations' talking points to discuss specific incidents in their history.

Together these strategies combined to be what I call, A Methodology of Access. By combining ethnography, partnership with a local non-profit, document analysis and interviews, I gained access far beyond what was typical in post-Katrina study. Such access helped with rigor, as it allowed for a fuller picture that included hard-to-reach organizations and issues, and it also helped with depth, as I knew about and could ask about hundreds of issues for each association. 


\section{Findings}

In examining 71 different relationships in the context of 42 interviews with 14 neighborhood associations in New Orleans, neighborhood associations repeatedly found themselves excluded from, or in conflict with, a policy network. Lacking traditional power in these situations, they exhibited what I call creative coercion, using levers outside the system to help gain influence in their power struggles.

Among the organizations I studied, there are myriad examples of conflict. Virtually every association that provided documents had evidence of exclusion and power struggles alongside the more traditional partnerships. Among these, three examples are the clearest examples of such conflicts, and display the broader pattern best. They show how neighborhood associations look for a creative lever outside the system, when they are excluded from networks. Their role in networks is not just as another group working together for a common goal, it is as an agitator, looking for a foothold to assure that their priorities are incorporated into the decision.

In the Historic Faubourg Lafayette Association, the former president explains her own struggle to protect her neighborhood from a proposed development of a grocery store. Historic Faubourg Lafayette is located in Central City, a historically African-American neighborhood in one of the most crime-ridden areas of New Orleans. The Historic Faubourg Lafayette Association opposed a proposed development in 1998 on several grounds. The first was the inappropriateness of the development. It was sprawling and suburban, with a large store and expansive parking lots. The opposition was also influenced by a desire for preservation. The development designs called for the demolition of eight historic homes.

The racial implications of preservation were used by local City Council Representative Oliver Thomas to discredit the association. Oliver Thomas was a rising star in a political machine in Central City run by former City Council Representative, Jim Singleton. He was supported of the project, and it appeared that the developer had bought all the property necessary to start development. With little legal power and no financial resources, the Historic Faubourg Lafayette Association had no means to impact the debate. Oliver Thomas undercut support for the neighborhood association further by referencing a coalition between the association and primarily white preservationists. At a public meeting to discuss the development, Oliver Thomas criticized neighborhood protest as being supported by white preservationists who did 
not live in the neighborhood. Although the president of the Historic Faubourg Lafayette Neighborhood Association was African-American, her association had only a few members. She reached out to the Felicity Street Redevelopment Project Inc., whose volunteers came from the nearby Garden District and were almost all white. Oliver Thomas used that fact against her.

The neighborhood association lacked public support, money or legal influence. But it was not content to let the development of the grocery store continue. Working on a local tip, the association's members discovered that one of the properties in the development area was still on the market. The developers only thought they had purchased it. This often occurs in relatively poor, African-American neighborhoods in New Orleans. Properties stay in the family for generations and paperwork is rarely up to date. As a result, developers believed they owned all the necessary properties and were caught unawares. Armed with information about the true owners of the home, the preservationist Felicity Street Redevelopment Project Inc. and the Historic Faubourg Lafayette Association approached a second grocery store that was eager to spite the development as it had lost on its own bid to develop the grocery store. The association elicited a six-figure donation from the grocery chain, then used that money to purchase the home. Under cover of darkness, and worried that the developer would discover their plot, they met with the homeowner and purchased the property.

The purchase slowed the development, and although it was eventually abandoned for other reasons, that purchase was considered to be a key moment in the policy process by interviewees from the Historic Faubourg Lafayette Association and collaborative partner Felicity Street Redevelopment Project Inc. It also gave them a stake in a policy process from which the association was excluded, by leveraging resources considered by others to have been outside of the process. As the Historic Faubourg Lafayette Association was excluded from the policy networks in its neighborhood, it grasped for another way to insert itself into the debate. It eventually took something extraneous, a donation from a rival developer and the purchase of a historic home affected, and used these things to insert itself into the policy network. This is what I call creative coercion.

The Algiers Point Association followed that same pattern in a conflict with Crescent City Connection. The Algiers Point neighborhood is across the Mississippi River from the rest of New Orleans. Known as the West Bank, many of the neighborhood residents commute into 
the downtown for work. Poorer residents often use the free ferry to cross into the French Quarter, where the tourism industry thrives and where they work at a variety of restaurants and stores. After Hurricane Katrina, the ferry service was suspended, and later opened with limited hours. This was an area of concern for residents of Algiers Point, as they found themselves stuck in the French Quarter because shifts ended after the ferry had closed for the night. As a result, many found themselves paying for taxis to return to their families after work, an added expense they could not afford. Neighborhood association meetings dealing with the ferry saw spiked attendance, and the association started an organization called Friends of the Ferry specifically to deal with the issue.

Friends of the Ferry interacted primarily with an organization titled Crescent City Connection that was in charge of all travel between the West Bank and New Orleans. According to members of the Algiers Point Association, Crescent City Connection repeatedly stated that there was not enough demand to justify running the ferry late into the evening, a curious claim because the ferry was free and there was no monetary impact from running the ferry with few riders. Friends of the Ferry, with no legal say in the matter, had no way to impact this decision. Facing a power deficit, Friends of the Ferry set about creating its own influence. It made public records requests and sorted through the records of the Crescent City Connection. In these records it found that Crescent City Connection had broken a political promise made to the West Bank. Along with the ferry, the other primary manner in which residents commute to and from New Orleans is via a bridge. This bridge has a toll, and many residents of the West Bank are forced to pay it in both directions each day. West Bank residents were promised that the toll money from this bridge would be reinvested into transportation issues that affected the West Bank, such as repairs to the bridge and funding of the ferry. The Crescent City Connection records revealed that instead of keeping the funds from the toll local, they were being used to fund highway repairs on the LA-1, far to the west of Algiers Point. Friends of the Ferry took this information to State Senator Pat Connick and the state senator used the information to place political pressure on the Crescent City Connection causing Crescent City to change the policy and revert to the full complement of hours.

Just as the Historic Faubourg Lafayette Association aggressively inserted itself into a policy negotiation, the Algiers Point Association found creative and coercive ways to insert itself into the governance network. 
A third example of creative coercion was the efforts of the president of the Northwest Carrollton Neighborhood Association. That president used a host of different creative techniques to be heard in different policy struggles. After Hurricane Katrina, the neighborhood association became involved in a conflict with a Walgreens pharmacy on a primary corner in the neighborhood. Similar to the development of the grocery store in Central City, the neighborhood association believed that the planned store model was too suburban and not respectful of the neighborhood and its history. The association engaged in a number of tactics to attempt to influence aspects of the development, from the direction the stores would face, to the look of the construction plans. At one point, it even engaged in what it cleverly called a 'guerrilla warfare’ approach that involved hanging handmade signs from the construction that lamented, 'Walgreens kills neighborhoods'. The association did deep research into the land use qualifications of the corner lot, finding that some of the plans were inconsistent with the legal requirements. Also, the association made the grocery store development an issue in an election. City Council candidate Shelly Midura included support of the neighborhood association against Walgreens as a plank of her platform in her campaign. When she was elected, she held a press conference in support of the Northwest Carrollton Neighborhood Association, which was cited as the turning point in the policy negotiations.

Again here, the neighborhood association, which was excluded from all meaningful aspects of a decision with quite a large impact on the neighborhood, found a creative way to insert itself into the policy negotiation. In this case, research and legal approaches complemented a broadly political strategy. Both were designed to give the association power at the negotiating table. The Northwest Carrollton Neighborhood Association received only minor concessions from Walgreens, but these included historically influenced designs as well as a shift in the back facade of the building so as not to screen out the neighborhood.

That was not the last time that the Northwest Carrollton Neighborhood Association was a thorn in the side of a policy network that sought to exclude them. Another critical issue after the storm was demolitions and blight. Mayor Ray Nagin and his administration asserted emergency powers for demolitions. The immediate problem was that damaged houses were collapsing, and causing other houses damage. But secondary problems emerged. Rumors of perfectly good houses being demolished without due process ripped through neighborhoods. 
The mayor was caught in a scandal with the New Orleans Affordable Housing (NOAH) in which houses were claimed to be demolished that did not exist.

The Northwest Carrollton Neighborhood Association featured two avid preservationists as its leadership. One started a blog that took pictures of thousands of homes so there would be a record if they were demolished without cause. She also worked on the NOAH story, helping expose the corruption behind the demolition process. The other leader, according to an interview with another neighbor, took even more extreme action. The president of the association was dismayed not only at the demolitions, but also at the lack of a response from her neighbors. So one night, she bought spray paint, and painted the demolition sign on a number of neighborhood houses. The result was immediate; now her neighbors were invested.

There were policy changes as a result of these creative and coercive measures. Emergency powers for demolitions were ended, and a board oversaw and approved demolitions. The leadership in the Northwest Carrollton Neighborhood Association took an issue in which they were completely excluded, and had no formal authority, and inserted themselves into the discussion.

The same thing was found all over New Orleans. The Sugar Hill Neighborhood Association opposed a land use measure by Dillard University to assure the university removed a program that placed ex-convicts in their neighborhood. The Dreux Avenue Good Neighbors Society used repeated police calls to attempt to protect their neighborhood from what they perceived to be a threat from a local apartment complex. The Upper Audubon Association used its political clout to oppose development by Tulane University that would have expanded student housing in their neighborhood.

These different examples of creative coercion all follow a pattern. A neighborhood association is excluded. That association lacks traditional power, financing or decisionmaking, so it searches for something outside the system. It then uses that creative, coercive technique to insert itself back into the process. 


\section{Conclusion}

The exclusion of neighborhood association in New Orleans policy networks and their ensuing conflicts, points out the need to reconsider these networks. Theory on networks, particularly within the work of Brown and Keast (2003) and network governance scholars (see Torfing 2005), views networks as partnerships with the potential to increase efficiency. In this paradigm, if a group of actors join together for a common goal, they stand a better chance of succeeding. The experience of neighborhood associations in post-Katrina New Orleans shows a different experience; there, policy networks are the location of power struggles.

Neighborhood associations, faced with exclusion, use creative and coercive measures to insert themselves into these networks.

The response to this exclusion by New Orleans' neighborhood associations fits within a broader debate on the agency and structure of power. Neighborhood associations are clearly disadvantaged by the structure around them; they have little in terms of resources or formal legislative clout. In this way, they have much in common with Scott's (1985) wielders of 'weapons of the weak' or those with Havel's ‘power of the powerless' (Havel et al. 1985). In both these situations, the challenge is to have a modicum of influence despite little structural power. Similarly, how-to guides to urban activism and community organizing, such as Alinsky's (1971) Rules for Radicals, provide a roadmap for asserting the same type of influence. Urban neighborhoods have long engaged in strategies to oppose development, fight for civil rights, or empower locals in politics.

While none of this is new or unique to New Orleans, it is new to the broader theories around networks and connection. Castells (1997, p. 425) argues that, 'The new power lies in the codes of information and in the images of representation around which societies organize their institutions, and people build their lives, and decide their behavior. The sites of this power are people's minds'. But this is an argument about the power of technology and media in uniting opposition, one Castells also makes in Networks of Outrage and Hope: Social Movements in the Internet Age (2013, p. 6) arguing, 'This networking is operated by the act of communication'. Similarly, classic social capital arguments (see Putnam 1995) focus on connections between those in communities, not the power dynamics between them.

So while the creative activity of neighborhood associations is not unique, it does make an important contribution to the understanding of networks. Specifically, these associations and 
their conflicts illuminate a model of how urban neighborhoods address their structural power deficit in the context of networks. The contribution is in the incorporation of these conflicts and strategies into an understanding of network formation and negotiation.

That model of how urban neighborhood associations work is called here, creative coercion. Cook (1972) coined the term, but this research both expands his concept and adds a strategic understanding to its use by grassroots and neighborhood organizations. While Cook sees coercion as morally neutral, he argues that coercion is creative when it is used for positive ends, often against the status quo. One example he gives is against racism in the South. Conrad (1974, p. 420) claims that this makes the term 'creative coercion' a rhetorical one, arguing 'Was Stalin's coercion of the kulaks ‘creative'? Was American bombing of North Vietnam 'creative'? It is clear that Cook thinks of coercion as 'creative' when he agrees with its objectives'. This research redefines creativity within coercion to refer to not to moral direction, but to a specific pattern of strategies used by those less powerful against authorities. The research then catalogues the pattern of strategies used by neighborhood associations in New Orleans.

The form of creative coercion established in this study, in which less powerful entities, here neighborhood associations, challenge more powerful authorities, has several characteristics.

The first characteristic is that the neighborhood association is excluded from a network. Sometimes this means the association is not a part of the network at all, and at other times the association remains in the network but does not have the influence to affect final decisions. As discussed above, this is already a reconceptualization of networks as being the location of power struggles rather than primarily the location of partnership.

The second characteristic of the creative coercion model is that neighborhood associations are at a structural power deficit; they have little money or formal decision-making power. This leaves them unable to use traditional strategies to leverage a spot within the network, or to influence the network.

Finally, the third characteristic of the creative coercion model is that in response to this power deficit, neighborhood associations are forced to find and pull a lever from outside of the current policy debate to force others in the network to give them a seat at the table. While the 
nature of innovation, creativity, and unexpected action make it difficult to make broad generalizations what these levers are, there are a number of levers commonly used. First, creative levers are often found by a small group of volunteers rather than wide unified action, a sharp delineation from Castells’ (2013) networks of outrage, which depend on greater numbers. Second, the creative action often involves the repurposing of a formal structure. For example, the Northwest Carrollton Neighborhood Association repurposed an election to make it about a local development issue. The association also repurposed blighted buildings to promote their message (and physically, their signs) that 'Walgreens kills neighborhoods.' Other neighborhoods repurpose structure in similar ways.

This creative coercion model draws from similar writing on community organizing tactics, but has a different purpose. Rather than provide a guide to community activists, it is an incorporation of power and agency theory into an understanding of networks.

Thus, this article makes two contributions to our understandings of networks. First, it moves beyond current theorizing that networks are primarily partnerships to be used to create more efficient government, to a conception of networks as the location of power struggles. The article also uses the conflicts of neighborhood associations to build the creative coercive model, which shows specifically how long-standing community organizing tools are used to battle exclusion from networks, and to garner power within them despite structural deficits of power.

\section{Bibliography}

Ahlers, D. \& Hummel, R. 2007, 'How a Community can Spearhead Successful Disaster Recovery', Available at: http://belfercenter.ksg.harvard.edu/files/uploads/DisasterRecoveryGuide_Phase_1.p df Accessed: 3/6/2009.

Alinsky, S.D. 1971, Rules for radicals: A Practical Primer for Realistic Radicals, Vintage, New York.

Anyon, J. 2005, Radical possibilities: public policy, urban education, and a new social movement, Routledge, New York.

Arnold, J.L. 1979, 'The neighborhood and City Hall', Journal of Urban History, vol. 6, no. 1, pp. 3-30. doi: http://dx.doi.org/10.1177/009614427900600101

Bingham, L.B., Nabatchi, T. \& O'Leary, R. 2005, 'The new governance: Practices and processes for stakeholder and citizen participation in the work of government', 
Public Administration Review, vol. 65, no. 5, pp. 547-558. doi:

http://dx.doi.org/10.1111/j.1540-6210.2005.00482.x

Birkland, T. A. 2008, 'Lessons of disaster: Policy change after catastrophic events', Public

Management Review, vol. 10, no.1, pp. 153-155. doi:

http://dx.doi.org/10.1080/14719030701783672

Blumler, J.G. \& Kavanagh, D. 1999, 'The third age of political communication: Influences and features', Political Communication, vol. 16, no. 3, pp. 209-230. doi: http://dx.doi.org/10.1080/105846099198596

Blyth, M. \& Katz, R. 2005, 'From catch-all politics to cartelisation: The political economy of the cartel party', West European Politics, vol. 28, no. 1, pp. 33-60. doi: http://dx.doi.org/10.1080/0140238042000297080

Bogason, P. \& Musso, J.A. 2006, 'The democratic prospects of network governance', The American Review of Public Administration, vol. 36, no. 1, pp. 3-18. doi: http://dx.doi.org/10.1177/0275074005282581

Brown, K.A. \& Keast, R.L. 2003, 'Citizen-government engagement: community connection through networked arrangements’, Asian Journal of Public Administration, vol. 25, no. 1, pp. 107-132.

Castells, M. 1996, Rise of the Network Society: The Information Age: Economy, Society and Culture, Vol. 1, Blackwell Publishers, Oxford.

Castells, M. 1997, The Power of Identity, vol. 2, Blackwell, Oxford.

Castells, M. 2013, Networks of Outrage and Hope: Social movements in the Internet Age, Polity Press, Cambridge.

Chamlee-Wright, E. 2008, 'Signaling effects of commercial and civil society in post-Katrina reconstruction', International Journal of Social Economics, vol. 35, no. 8, pp. 615626. doi: http://dx.doi.org/10.1108/03068290810889233

Cigler, B. 2001, 'Multiorganizational, multisector, and multicommunity organizations: setting the research agenda', in Mandell, M. (ed) Getting Results through Collaboration: Networks and Network Structures for Public Policy and Management, Quorum Books, Westport, CT, pp. 71-85.

Conrad, T. 1974, 'Coercion, Assassination, Conspiracy: Pejorative Political Language', Polity, vol. 6, no. 3, pp. 418-423. doi: http://dx.doi.org/10.2307/3233937

Cook, S. 1972, 'Coercion and Social Change’, in Pennock, J. and Chapman, J. (eds.) Coercion: Nomos XIV, Aldine-Atherton Inc., New York, NY, pp. $143 f f$.

Crozier, M. 2008, 'Listening, Learning, Steering: New Governance, Communication and Interactive Policy Formation', Policy \& Politics, vol. 36, no. 1, pp. 3-19. doi: http://dx.doi.org/10.1332/030557308783431616

Dahl, R.A. 1961, Who governs? Democracy and Power in an American City, Yale University Press, New Haven, CT.

Daka-Mulwanda, V., Thornburg, K.R., Filbert, L. \& Klein, T. 1995, 'Collaboration of services for children and families: A synthesis of recent research and recommendations', Family Relations, vol.44, pp. 219-223. doi: http://dx.doi.org/10.2307/584812

De Tocqueville, A. 1835, Democracy in America, Gateways Edition, Regenery Publishing, Washington DC. 
Forrest, J.B. 2003, 'Networks in the policy process: An international perspective', International Journal of Public Administration, vol. 26, no. 6, pp. 591-608. doi: http://dx.doi.org/10.1081/PAD-120019237

Foucault, M. 1978, The History of Sexuality, Pantheon Books, New York.

Gaventa, J. 2003, 'Power after Lukes: an overview of theories of power since Lukes and their application to development', Brighton: Participation Group, Institute of Development Studies.

Goldsmith, S. \& Eggers, W.D. 2004, Governing by Network: The New Shape of the Public Sector, Brookings Inst Press, Washington DC.

Gray, B., 1989, Collaborating: Finding Common Ground for Multi-Party Problems, JosseyBass, San Francisco, CA.

Havel, V. 1985, 'The power of the powerless', in Keane, J. (ed.), The Power of the Powerless: Citizens Against the State in Central-Eastern Europe, Hutchinson, London, pp. 2396.

Hayward, C., \& Lukes, S. 2008, 'Nobody to shoot? power, structure, and agency: A dialogue', Journal of Power, vol. 1, no.1, pp. 5-20. doi: http://dx.doi.org/10.1080/17540290801943364

Hogue, T. 1993, 'Community-based collaboration: Community wellness multiplied', Oregon State University, Oregon Center for Community Leadership, Corvallis.

Hunter, F. 1969, Community Power Structure: A Study of Decision Makers, University of North Carolina Press, Chapel Hill, NC.

Jones, C., Hesterly, W.S. \& Borgatti, S.P. 1997, 'A general theory of network governance: Exchange conditions and social mechanisms', The Academy of Management Review, vol. 22, no. 4, pp. 911-945. doi: http://dx.doi.org/10.2307/259249

Katz, B., \& Bradley, J. 2013, The metropolitan revolution: How cities and metros are fixing our broken politics and fragile economy, Brookings Institution Press, Washington DC.

Katz, R.S. \& Mair, P. 1995, 'Changing models of party organization and party democracy', PartyPolitics, vol. 1, no. 1, pp. 5-28. doi: http://dx.doi.org/10.1177/1354068895001001001

Kooiman, J. 1993, Modern Governance: New Government-society Interactions, Sage, Thousand Oaks, CA.

Lawson, H. 2002, 'Improving conceptual clarity, accuracy, and precision and facilitating more coherent institutional designs', in The Contribution of Interprofessional Collaboration and Comprehensive Services to Teaching and Learning, The National Society for the Study of Education Yearbook, NSSE, Chicago, pp. 30-45.

Litterer, J.A. 1973, The Analysis of Organizations, Wiley Press, Chichester.

Lukes, S. 1974, Power: A Radical View, McMillan Press, London.

Mandell, M. \& Steelman, T. 2003, 'Understanding what can be accomplished through interorganizational innovations; The importance of typologies, context and management strategies', Public Management Review, vol. 5, no. 2, pp. 197-224. doi: http://dx.doi.org/10.1080/1461667032000066417

Mayhew, D.R. 2002, America's Congress: Actions in the Public Sphere, James Madison through Newt Gingrich, Yale University Press, New Haven. 
Melaville, A.I. \& Blank, M.J. 1991, What It Takes: Structuring Interagency Partnerships to Connect Children and Families with Comprehensive Services, Education and Human Services Consortium, Washington DC.

Mulford, C.L. \& Rogers, D.L. 1982, 'Definitions and models', in Rogers, D. \& Whetten, D. (eds.) Interorganizational coordination: Theory, Research and Implementation, Iowa State University Press, Des Moines, pp. 9-31.

Ornstein, N.J. \& Mann, T.E. 2000, The Permanent Campaign and its Future, American Enterprise Institute Press, Washington, D.C.

Provan, K.G. \& Kenis, P. 2008, 'Modes of network governance: Structure, management, and effectiveness', Journal of Public Administration Research and Theory, vol. 18, no. 2, pp. 229-252. doi: http://dx.doi.org/10.1093/jopart/mum015

Rhodes, R. A., W. 1996, 'The New Governance: Governing without government', Political Studies, vol. 44, no. 4, pp. 652-667. doi: http://dx.doi.org/10.1111/j.1467-9248.1996.tb01747.x

Scott, J. C. 1985, Weapons of the weak everyday forms of peasant resistance, Yale University Press, New Haven, CT.

Sørensen, E. \& Torfing, J. 2005, 'The democratic anchorage of governance networks', Scandinavian Political Studies, vol. 28, no. 3, pp. 195. doi: http://dx.doi.org/10.1111/j.1467-9477.2005.00129.x

Stablein, 1996, Handbook of Organization Studies, Sage, Thousand Oaks, CA.

Stoker, G. 1998, 'Governance as theory: five propositions', International Social Science Journal, vol. 50, no. 155, pp. 17-28. doi: http://dx.doi.org/10.1111/1468-2451.00106

Torfing, J. 2005, 'Governance network theory: towards a second generation', European Political Science, vol. 4, no. 3, pp. 305-315. doi: http://dx.doi.org/10.1057/palgrave.eps.2210031

Winer, M. \& Ray, K. 1994, Collaboration Handbook: Creating, Sustaining, and Enjoying the Journey. Amherst H. Wilder Foundation, St. Paul, MN. 